\title{
The Role of Extension in Promoting Kartu Tani to Farmer Adoption Rate in Pati Regency
}

\author{
Ardian Ozzy Wianto ${ }^{1}$, Drajat Tri Kartono ${ }^{2}$, Dwiningtyas Padmaningrum ${ }^{3}$ \\ ${ }^{1}$ Postgraduate, Development Counseling Study Program, Sebelas Maret University, \\ Indonesia \\ ${ }^{2}$ Sociology Study Program, Faculty of Social and Political Sciences, Sebelas Maret University, \\ Indonesia \\ ${ }^{3}$ Agricultural Extension and Communication Study Program, Faculty of Agriculture, Sebelas \\ Maret University, Indonesia \\ Email: ardie.ozzy250@gmail.com
}

\begin{abstract}
The agricultural sector plays an important role in economic growth in Indonesia. Central Java is one of the provinces contributing to the largest agricultural production in Indonesia. The role of the government in improving agricultural productivity in Indonesia is to provide facilities in the form of subsidized fertilizer to farmers by using an electronic card-based redemption innovation (Kartu Tani). Pati Regency in 2018 is one of the districts with the highest Kartu Tani users in Indonesia, although the target number of uses has not met expectations. This study aims to analyze the role of extension agents in promoting the innovation of Kartu Tani on the level of farmers' adoption of innovation in the Pati Regency. This research is quantitative research with explanatory type. The analysis technique used in this study is simple Linear Regression; The sample consists of 150 farmers who have a Kartu Tani. The results showed that the role of extension agents in promoting innovation did not significantly influence $(P>$ 0.05) on the level of farmers' adoption of innovation in the Pati Regency. This shows that there is no influence on the role of extension agents in promoting innovation towards farmers in adopting the Kartu Tani innovation. Farmers get Kartu Tani information from fellow farmers because of the limited number and extension of instructors' time in providing information to farmers.
\end{abstract}

Keywords: Level of Adoption, Kartu Tani, Farmers.

\section{A. INTRODUCTION}

Agricultural development in Indonesia aims to realize several main achievements, namely the realization of a competitive agricultural system, the achievement of independent food security, and the creation of full employment opportunities for agricultural communities. Agriculture has become one of the components of national development towards food self-sufficiency to reduce poverty (Nirmawati, 2014). The agricultural sector is one of the top priorities in increasing economic growth in Indonesia. The agricultural sector plays an important role in providing food for the entire population as well as providing raw materials for industry, and for export trade (Suparta in Dewi, 2016). Agriculture is very dependent on the availability of farming inputs, namely the 
availability of seeds, agricultural equipment, the use of pesticides, and the use of fertilizers. Fertilizer is one of the important and strategic elements for increasing production, crop productivity, and farmers' income in an effort to build national food security. Fertilization aims to replace lost nutrients and increase the supply of nutrients needed by plants to increase crop production and quality.

According to Nyanjang (2003), the availability of complete and balanced nutrients that can be absorbed by plants is a factor that determines plant growth and production. The application of balanced fertilization needs to be supported by accessibility in obtaining fertilizer at an affordable price. The obstacle faced by farmers in obtaining fertilizer subsidies is the scarcity and price of fertilizer exceed the highest specified retail price. According to Darwis and Muslim (2007), the scarcity of fertilizer at the farm level is a logical consequence of the weakness of the distribution system, particularly related to aspects of fertilizer distribution, storage, and marketing. Based on these problems, we need innovation.

Innovation is an idea, ideas, practices, or objects that are realized and accepted as something new by a person or group to be adopted (Robbins, 1994). Adoption in the counseling process (agriculture), in essence, can be interpreted as a process of change in behavior in the form of knowledge (cognitive), attitude (affective), and skills (psychomotor) in a person after receiving "innovation" conveyed by the instructor to the target community. Rogers (2003) states that innovation is an idea, action, or item that is considered new by someone. According to Mierlo and Leeuis in Micheels and Nolan (2016) defining agricultural innovation is not only about adopting new technologies but also requires a balance between new technical practices and alternative ways of organizing. Agricultural innovation increases productivity and contributes to reducing household food insecurity (Tambo \&Wunscher, 2018).

The role of the government in ensuring the distribution of subsidized fertilizers in Central Java is in accordance with the principle of 6 (six) right, that is, the exact amount, type, time, place, quality and price of the government to make innovative redemption of subsidized fertilizer based on electronic cards in the form of Farmers Cards so that the distribution of subsidized fertilizer guaranteed. The Ministry of Agriculture cooperates with the Association of State Banks (Himbara) in the process of making Kartu Tanis. Each Bank incorporated in Himbara is given responsibility in one province namely Bank Negara Indonesia (BNI) for East Java Province, Bank Rakyat Indonesia (BRI) for Central Java Province, Bank Mandiri for West Java Province and State Savings Bank (BTN) for Banten Province. The Kartu Tani Program in Central Java Province is a subsidized fertilizer program for farmers in the form of a debit card that is used specifically to read subsidized fertilizer allocations and subsidized fertilizer payment transactions in the BRI Electronic Bank (EDC) machine (Bank Rakyat Indonesia) placed at a fertilizer retailer and can function to conduct all banking transactions in general (Moko, 2017). The Kartu Tani includes information on the Definitive Plan for Farmer Group 
Needs (RDKK) for each type of subsidized fertilizer, namely Urea, ZA, SP-36, NPK, and organic. The Kartu Tani Program is expected to ensure transparency and accountability in the distribution of subsidized fertilizer to farmers or farmer groups. Through the use of the Kartu Tani, it is expected that the distribution of subsidized fertilizer will be more secure and targeted to farmers who are entitled to receive it. The use of Kartu Tanis will facilitate the government in controlling the circulation of fertilizers in Indonesia (Febriani, 2018). The fertilizer subsidy and distribution policy have been implemented comprehensively starting from the needs planning stage, setting the highest retail price (HRP), the amount of the subsidy to the distribution system to fertilizer users (Rachman \& Sudaryanto, 2010).

Central Java Province is one of the pioneers of the Kartu Tani program and serves as a pilot for other provinces in Indonesia (Jatengprov.go.id, 2017). Pati Regency is one of the regencies in Central Java Province that has implemented the Kartu Tani program. Pati Regency was ranked first in achieving the use of Kartu Tanis in Central Java, which amounted to 46.27 percent in 2018. Although it became the district that had the most usage, in reality the target was not as expected. The target of the Kartu Tani application in 2018 is 50 percent. One of the problems hampering the use of the Kartu Tani is that farmers are still suspected of feeling difficulties and do not understand the use of the Kartu Tani. Here the role of extension workers is needed in influencing farmers' decision making to adopt and assist farmers in overcoming the Farmers Card problem. According to Lamarang (2017), extension activities are one of the efforts that have an important role in increasing knowledge, skills, and attitudes. The role of extension workers not only conveys information to farmer-livestock but must also be able to add, change, and build aspects of knowledge (cognitive), attitudes (affective), and skills (psychomotor). According to Rogers (2003), farmer adoption is influenced by various factors, one of the factors influencing the adoption rate of farmer innovation is the role of extension workers in promoting innovation. This study aims to analyze the influence of the role of instructors in promoting the innovation of Kartu Tani on the level of adoption of farmer innovation in the Pati Regency.

\section{B. MethoD}

This research was conducted in Pati Regency, one of the regencies in Central Java Province, Indonesia. The location of the study was determined intentionally (purposive) based on certain considerations (Andi, 2016). The determination of the location of the study was based on the highest percentage of Kartu Tani use in Central Java province, Pati Regency. Pati Regency was ranked first in the use of the Kartu Tani program in Central Java in 2018 with a total of 41,393 cards used.

This study uses a quantitative approach that emphasizes its analysis of numerical data (numbers) that are processed by statistical methods. The use of quantitative methodology will obtain the significance of the relationship between the variables studied 
(Fitri et al., 2016). Quantitative research is a research method that aims to describe social phenomena or phenomena quantitatively or explain how social phenomena or phenomena that occur in society are related to one another. Based on its purpose, this research is explanatory research that is research that seeks to explain why a phenomenon or social phenomenon occurs by connecting one phenomenon with another phenomenon. This type of research is explanatory research, namely research that explains causal relationships between variables through hypothesis testing (Effendi \& Tukiran, 2014).

Sub-district sampling based on the sub-district that has the highest number of user farmers, namely Sukolilo Sub-district and the sub-district with the smallest number of farmers is Tayu Subdistrict, then each sub-district is taken by the village with the highest number of Kartu Tani holders, namely Tompegunung Village in Sukolilo Subdistrict and Dororejo Village in Subdistrict Tayu; and the lowest number of Kartu Tani holders, namely Wegil Village in Sukolilo District and Bulungan Village in Tayu District. The number of samples in this study was 150 farmer respondents by referring to Sugiono's opinion (2013). This study uses a simple linear regression analysis technique to examine the effect of independent variables (independent variables) on the dependent variable (the dependent variable) (Permatasari et al., 2018). The independent variable is stated in $\mathrm{Y}$ while the dependent variable is stated in $\mathrm{X}$.

\section{Result AND Discussion}

The role of the instructor in this research includes the delivery of information on the success of the Kartu Tani, the solution to the Kartu Tani problem, and the socialization of the use of the Kartu Tani. The distribution of respondents based on the role of instructors in promoting the innovation of the Kartu Tani in Pati Regency is included in the low category, as many as 74 people (49.33\%). The distribution of respondents in this study can be seen in Table 1.

Table 1 Distribution of Respondents by Role of Extension Workers in Promoting Kartu Tani Innovations

\begin{tabular}{cccccc}
\hline \hline No & Information & Score & Category & $\begin{array}{c}\text { Number of } \\
\text { People }\end{array}$ & $\begin{array}{c}\text { Percentage } \\
\mathbf{( \% )}\end{array}$ \\
\hline 1 & The Extensions & $19-23$ & Very Low & 34 & 22,67 \\
& $24-28$ & Low & 74 & 49,33 \\
& $29-33$ & Medium & 22 & 14,67 \\
& $34-38$ & High & 19 & 12,67 \\
& $39-43$ & Very High & 1 & 0,67 \\
\hline & & & 150 & 100,00 \\
\hline \hline
\end{tabular}

Source: Primary Data Analysis, 2019

This shows that the role of instructors is not sufficient in conducting business promotion of Farmers Cards to farmers. Farmer respondents felt that they did not get information on the success of the Kartu Tani that had been running in other areas from 
the instructor and the solution to the problem of fertilizer allocation felt by farmers that the allocation was insufficient. This is not in accordance with the opinion (Al-Shayaa et al., 2012) which states that if there is a lack of knowledge or information among farmers, the instructor must provide technical information. The respondent farmer only gets the dissemination of the Kartu Tani from the instructor when the Kartu Tani will be distributed to farmers. The information provided by the instructor is the benefits of the Kartu Tani, so farmers' understanding of the process of using the Kartu Tani is not good. There is a need for assistance from extension agents to farmers in the process of using the Kartu Tani so that farmers can understand and use the Kartu Tani well

The success of the instructor's role is influenced by the level of compliance with the needs of the target. The influence of the role of extension agents on the adoption of the Kartu Tani innovation in Pati can be seen in table 2.

Table 2 Factor Analysis of the Role of Instructors in Influencing the Adoption of Farmer Innovations to the Kartu Tani Program

\begin{tabular}{lrccc}
\hline \multicolumn{1}{c}{ Uraian } & $\boldsymbol{\beta}$ & T Count & Sig. & Information \\
\hline (Constant) & 19,907 & 5,650 & 0,000 & \\
The Role of Extension & 0,031 & 0,239 & 0,811 & Not significant \\
\hline \hline
\end{tabular}

Source: Primary Data Analysis, 2019

Table 2 shows that the role of instructors with the adoption of the Kartu Tani innovation obtained prob.sig value is $0.811>\alpha 0.05$, then Ho is accepted, which means the role of the instructor does not significantly influence the adoption of the Kartu Tani innovation in Pati Regency. The role of extension workers will not affect the adoption of farmer innovations in the Farmers Card in Pati Regency. This is not in accordance with the opinion of Rogers (2003) which states that the more often the instructor promotes innovation, the adoption process will be relatively faster.

Farmers will continue to adopt Kartu Tani innovations even though the role of extension agents in promoting innovation is not good. The role of extension workers not only introduces and explains innovations to farmers but also makes efforts to encourage farmers to adopt Kartu Tani innovations. According to Bandura (2004), the importance of power to change one's behavior is not only determined or assessed by the power of explanation and prediction. Farmers do not pay attention to the role of extension workers as long as nothing prevents farmers from getting subsidized fertilizer. Farmers feel that the most important thing is that they can get subsidized fertilizer and not experience scarcity of fertilizer. The results of this study are in line with the research of Harinta (2011) who found that there was no significant influence between the role of extension workers on the level of adoption of agricultural innovations.

The results of this study are different from the opinion of Hanafi (1987) which states that the speed of adoption is also influenced by the incessant promotional efforts undertaken by reform agents. The reform agent's hard work was marked by their more 
frequent presence in the field than in the office. They more often make contact with their clients, especially personal contacts to spread innovation. The same thing was said by Bonjean (2019), that intensive knowledge transfer by extension agents would result in high adoption rates. Farmers get Kartu Tani information from fellow farmers because the number and time of extension workers are limited in providing information to farmers. This is consistent with the opinion of Donkor and Owusu (2014) which states that farmers are more likely to seek agricultural information and advice from fellow farmers because of the limited number of agricultural extension workers.

Kartu Tani information obtained by farmers from fellow farmers will shape the attitude of farmers in the process of rejecting or accepting Kartu Tani innovations. The results of this study are in line with the research of Indraningsih (2011) which states that the head of the farmer group teaches and influences other members of the farmer group. "Farmers learn from other farmers" is an effective approach to introducing integrated farming technology. The approach to communication channels through interpersonal media is an effective mechanism in bringing change to rural dryland areas such as Talaga Cianjur Village and Jatiwangi Garut Village. This is consistent with the opinion of Rogers (2003) which states that interpersonal communication channels are more effective in forming attitudes towards innovation and influencing decisions to accept or reject. Farmers trust more information obtained from fellow farmers. This is in line with the results of research by Gonzales and Israel (2010) which show that client preferences in choosing communication channels (mass media or interpersonal media) are determined by the benefits obtained, costs incurred and the level of trust in the source of information. Farmers adopt the Kartu Tani after getting information from other farmers who have already adopted it. This is in accordance with Rogers's opinion in Jahanmir and Cavadas (2018) which states that they adopt an innovation after the majority of users have adopted it because it is considered a safe action. Their adoption process is very dependent on other users. Farmers will continue to adopt the Kartu Tani innovation to maintain the sustainability of their agricultural land use, even if it is not influenced by the role of extension workers. This is consistent with the opinion of Rantala et al (2018) which states that the adoption of an innovation in agriculture will increase the sustainability of land use.

\section{CONCLUSION}

The results showed that the role of extension agents did not significantly influence the adoption of the Kartu Tani innovation in Pati Regency. Farmers get Kartu Tani information from fellow farmers because of the limited number and extension of instructors' time in providing information to farmers. Farmers will continue to adopt Kartu Tani innovations despite the role of instructors in promoting innovation. Extension workers are less intensive in providing information about the Kartu Tani program to farmers, so farmers look for information from fellow farmers who have already ap- 
plied it and members of their farmer groups. Related to the role of extension agents, extension agents should provide information more often, conduct outreach and assistance to assist farmers in finding solutions to problems experienced by farmers in the use of Kartu Tani innovations.

\section{REFERENCES}

1. Al-Shayaa, M. S., Baig, M. B., \& Straquadine, G. S. (2012). Agricultural extension in the Kingdom of Saudi Arabia: Difficult present and demanding future. Journal of Animal and Plant Sciences, 22, 239-246.

2. Bandura, A. (2004). Health promotion by social cognitive means 5. Health Education $\mathcal{E}$ Behavior, 31(2), 143-164.

3. Bonjean Isabelle. (2019). Heterogeneous incentives for innovation adoption: The price effect on segmented markets. Journal Food Policy, 87, 1-13.

4. Central Java Provincial Government. (2017). Kartu Tani Jateng Percontohan 17 Provinsi. Retrieved from https://jatengprov.go.id/publik/kartu-tani-jateng-percontohan17provinsi/.

5. Darwis, V., \& Muslim, C. (2007). Revitalisasi kebijakan sistem distribusi pupuk dalam mendukung ketersediaan pupuk bersubsidi di tingkat petani. Jurnal Ekonomi dan Pembangunan, 15(2), 141-168.

6. Dewi, N. L. P. K. (2016). Analisis Tingkat Usahatani Padi Sawah sebagai dampak dari adanya Subsidi Pupuk di Kabupaten Tabanan. Jurnal Agribisnis dan Agrowisata, 5(1).

7. Donkor, E., \& Owusu, V. (2014). Effects of land tenure systems on resource-use productivity and efficiency in Ghana's rice industry. African Journal of Agricultural and Resource Economics, 9(311-2016-5617), 286-299.

8. Effendi, S., \& Tukiran. (2014). Metode Penelitian Survei. Jakarta: LP3ES.

9. Ukhtia, F., Reza, I. F., \& Zaharuddin, Z. (2016). Hubungan Antara Religiusitas Dengan Kecemasan Akademik Pada Siswa Madrasah Aliyah Negeri. Psikis: Jurnal Psikologi Islami, 2(2), 149-160.

10. Galindo-Gonzalez, S., \& Israel, G. D. (2010). The influence of type of contact with extension on client satisfaction. Journal of Extension, 48(1), 1-14.

11. Hanafi, A. (1987). Memasyarakatkan Ide-Ide Baru. Surabaya: Usaha Nasional.

12. Harinta, Y. W. (2011). Adopsi inovasi pertanian di kalangan petani di Kecamatan Gatak Kabupaten Sukoharjo. Jurnal Agrin, 15(2), 164-174

13. Indraningsih, K. S. (2011). Pengaruh penyuluhan terhadap keputusan petani dalam adopsi inovasi teknologi usahatani terpadu. Jurnal Agro Ekonomi, 29(1), 1-24.

14. Jahanmir, S. F., \& Cavadas, J. (2018). Factors affecting late adoption of digital innovations. Journal of Business Research, 88, 337-343. 
15. Lamarang, Z., Sondakh, B. F., Rintjap, A. K., \& Sajow, A. A. (2017). Peranan Penyuluh Terhadap Pengambilan Keputusan Peternak Dalam Adopsi Inovasi Teknologi Peternakan Di Kecamatan Sangkub Kabupaten Bolaang Mongondow Utara. ZOOTEC, 37(2), 496-507.

16. Micheels, E. T., \& Nolan, J. F. (2016). Examining the effects of absorptive capacity and social capital on the adoption of agricultural innovations: A Canadian Prairie case study. Journal Agricultural Systems, 145, 127-138.

17. Moko, K. W., Suwarto, S., \& Utami, B. W. (2017). Perbedaan Persepsi Petani terhadap Program Kartu Tani di Kecamatan Kalijambe Kabupaten Sragen. Caraka Tani: Journal of Sustainable Agriculture, 32(1), 9-13.

18. Nirmawati, N., \& Tangkesalu, D. (2014). Analisis Efisiensi Penggunaan Input Produksi Usahatani Padi Sawah di Desa Harapan Jaya kecamatan Bumi Raya Kabupaten Morowali. Agrotekbis, 2(6), 645-651.

19. Nyanjang, R., Salim, A. A., \& Rahmiati, Y. (2003). Penggunaan pupuk majemuk NPK 25-7-7 terhadap peningkatan produksi mutu pada tanaman teh menghasilkan di tanah andisols. PT. Perkebunan Nusantara XII. Prosiding Nasional. Gambung. pp. 181-185.

20. Permatasari, P., Sapja, A., \& Widyatmani, S. D. (2018). Pengaruh Tingkat Adopsi Budidaya Padi Organik terhadap Keberlanjutan Budidaya Padi Organik di Kabupaten Boyolali. Caraka Tani: Journal of Sustainable Agriculture. 33(2): 153-168.

21. Rachman, B., \& Sudaryanto, T. (2016). Impacts and future perspectives of fertilizer policy in Indonesia. Analisis Kebijakan Pertanian, 8(3), 193-205.

22. Rantala, T., Ukko, J., Saunila, M., \& Havukainen, J. (2018). The effect of sustainability in the adoption of technological, service, and business model innovations. Journal of cleaner production, 172, 46-55.

23. Robbins, S. P. (1994). Organization Behavior. Australia: Prentice Hall.

24. Rogers, E. M. (2003). Diffusion of Innovation. New York: Free Press.

25. Tambo, J. A., \& Wünscher, T. (2018). Building farmers' capacity for innovation generation: Insights from rural Ghana. Renewable Agriculture and Food Systems, 33(2), 116-130. 